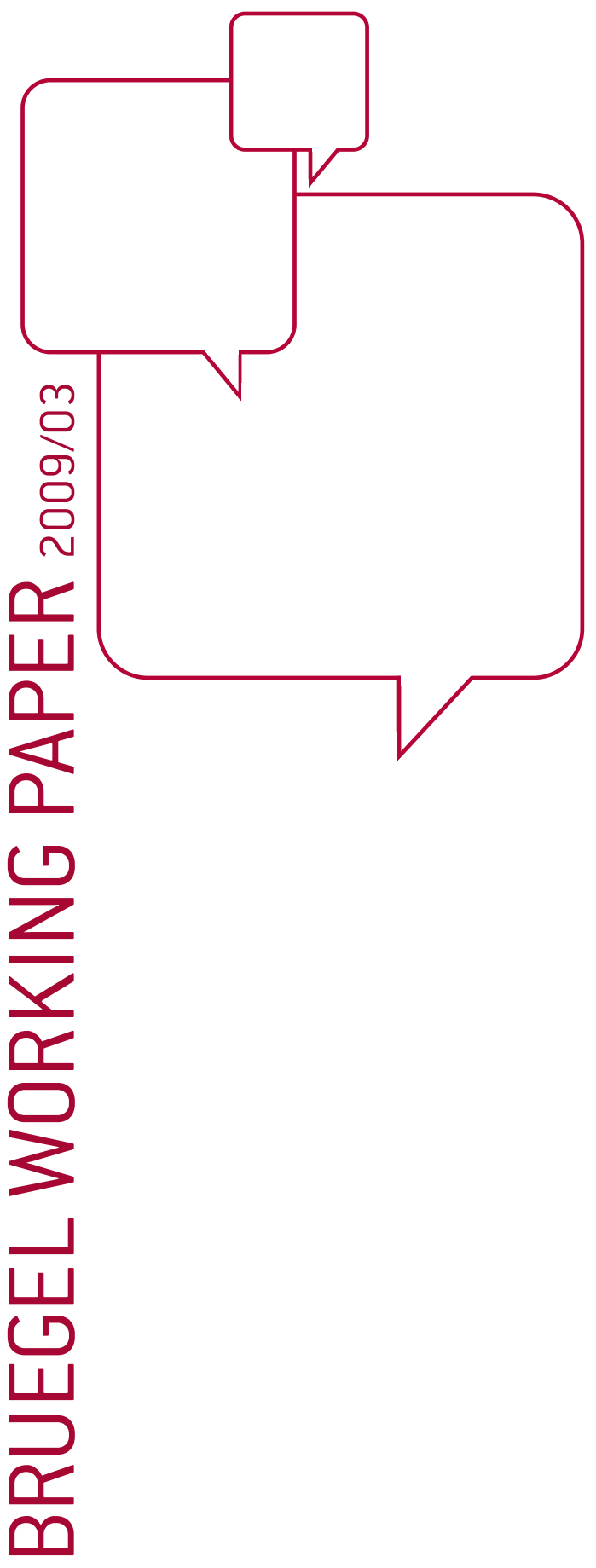

\title{
REFRAMING THE
} EU BUDGET

DECISION-MAKING PROCESS

INDHIRA SANTOS AND SUSANNE NEHEIDER

Highlights

- The EU budget review process will restart as we approach the end of the current financial framework 2007-2013. This paper traces the history of the EU budget and draws lessons for the review to come.

- Whatever reforms are proposed, they must serve to shift spending to policy areas and instruments where the EU can best add value while at the same time recognising the political need for member states to present EU budget negotiation results in 'net-balance' terms.

- A two-stage negotiation is proposed: first member states should negotiate and agree on what constitute EU public goods, to be financed in proportion to GNI shares.

Everything else would thereafter - by default - be deemed redistributive/compensatory spending to be financed, at least at the start, on the basis of member states' current overall net balances. 


\section{Reframing the EU budget decision-making process}

\section{Introduction}

"As it stands today [in 2003], the EU budget is a historical relic. Expenditures, revenues and procedures are all inconsistent with the present and future state of EU integration."

The Sapir Report, 2003, p 162.

The European Community's policy goals and instruments have been subject to dynamic development in the course of the integration process. The Single Market, Monetary Union, consecutive rounds of enlargement and the Lisbon Strategy are, to mention but a few, highlights of this process. The EU budget has served as a tool to facilitate this development by reflecting bargains necessary to secure member states' support. The Community budget has, as a result, been seen since the early days of the EU project as the product of successive intergovernmental side-payments made to facilitate integration or achieve consensus on certain policies. But this process has also left the EU budget in a weak position to help achieve the goals of the Union.

There is major scepticism about the EU budget and many questions are raised about its economic rationale and its effectiveness (Sapir et al. 2003, Gros and Micossi 2005, Begg and Heinemann 2006). There are two overarching issues that every few years bring strong disagreement and marathon budgetary negotiation sessions among member states. One is the spending structure. There are questions about the value added of EU fiscal intervention in certain policy areas like agriculture and at the same time the absence or minor role of the EU in other areas with clear spillovers such as defence and security. The second, and related, issue refers to financial burden-sharing. Depicting merely a cash flow of input, net positions 
tell us little about the effects of EU policies. They are nonetheless a driving force in budget negotiations and are persistently used as a reference point for negotiations. Furthermore, a focus on financial net balances often complicates discussions on expenditures and has a negative effect on the quality of EU intervention. However, one must also recognise that preoccupation with net balances is inevitable, even though they do not capture many of the economic benefits of European integration.

With this paper, we seek to contribute to the discussion on the reform of the EU budget by focusing on the decision-making-process of the EU financial framework (the so-called 'financial perspectives'). On our view, changing the process is a necessary - if not sufficient condition for any significant reform of the EU budget. We propose, in line with other authors, to separate public good expenditures - those where EU intervention improves the welfare of EU citizens in general - from the rest of the budget. Contrary to schemes that fix in advance what is to be considered as an EU public good, we suggest leaving that decision to the negotiating process. Those policies that achieve the unanimous support of member states, therefore revealing expenditures backed by a common interest, are to be considered as EU public goods. Reflecting member states' ability to pay, public goods should be financed proportionally to GNI shares. All remaining policies, by default, are to be pooled in a second category where net balances are negotiated.

Our proposal, while not automatically leading to drastic compositional changes in expenditure, would clarify the debate by making the trade-offs between allocation and (re)distribution explicit. By increasing transparency about the nature of EU expenditures it would create incentives to move towards category 1 or EU public goods expenditures. It then becomes harder to justify other expenditures that are mainly redistributive and not accepted by all member states. 
The remainder of this paper is organised as follows. Section 2 gives a general overview of the EU budget's role and composition and focuses on the role of net financial balances in determining the outcome of budgetary negotiations throughout the history of the EU budget. Section 3 reviews existing proposals to reform the EU budget decision-making process, identifying their strengths and the shortcomings that persist. Finally, in the concluding section we discuss our reform proposals and assess their possible impact on member states' budgetary net financial balances.

\section{Net balances and budgetary outcomes}

The EU budget is the financial instrument of the EU and includes all revenue and expenditure of the Union. As such, the budget is one of several instruments available to the EU to implement its policies and carry out its objectives, in addition to regulation, coordination and delegation. Since not all policy areas require a budgetary counterpart and only some policy areas fall under the responsibility of the EU, the EU budget is small compared to the size of national budgets or those of federal governments. In 2008, the EU budget amounted to $€ 129.1$ billion, representing $1.03 \%$ of the Community GNI and $2.5 \%$ of EU public spending (Figure 1, overleaf). 
Figure 1: EU expenditures 1960-2006

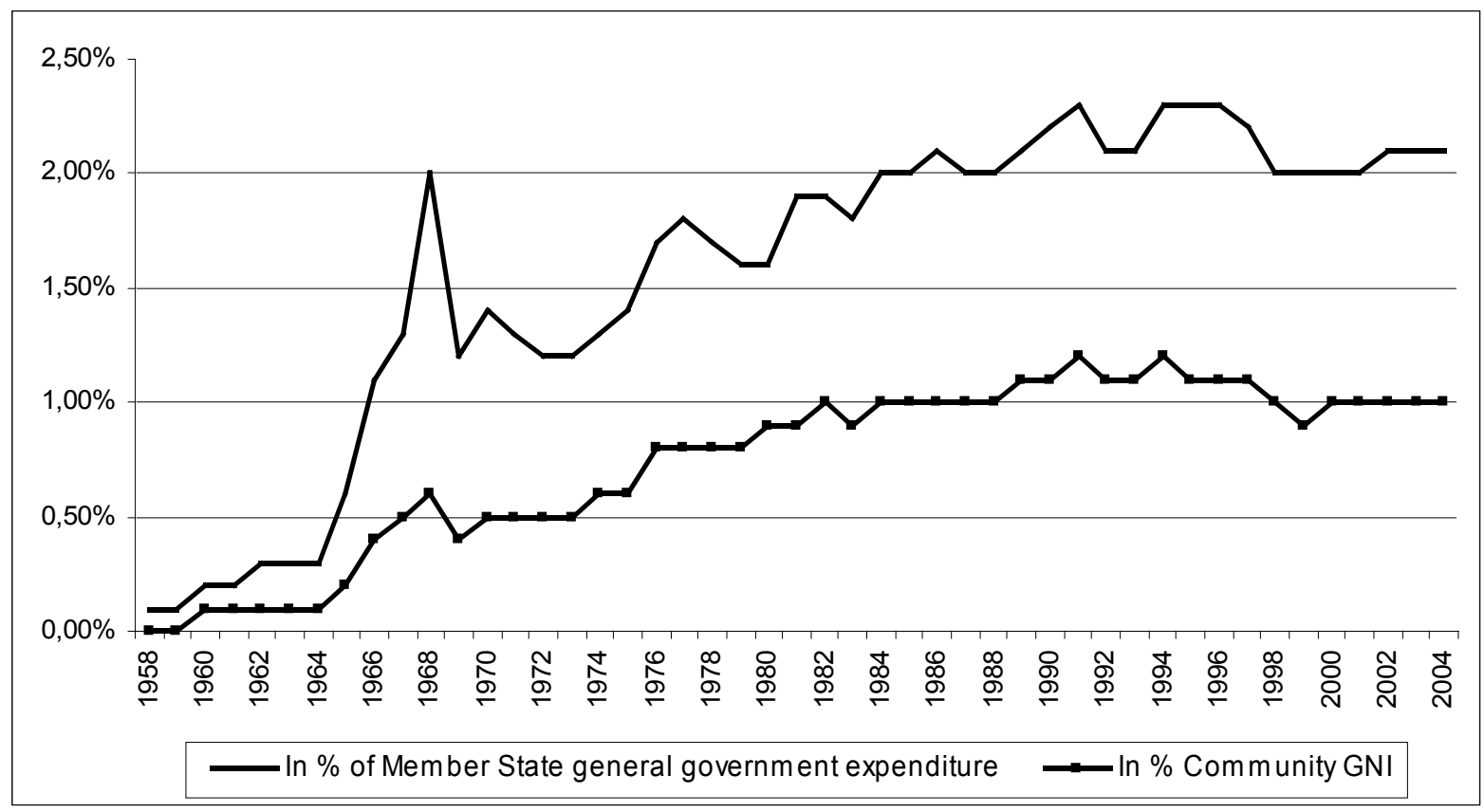

Source: European Commission (2008), EU Budget 2007. Financial Report

Since 1988, the EU budget has been embedded in a multiannual financial framework - agreed by the European Commission, the European Parliament (EP) and the Council - that fixes the amounts to be dedicated to specific policy headings. Figure 2 presents the breakdown of EU expenditure for the period 2007-2013. The largest single expenditure item is the Common Agricultural Policy (CAP) representing $42 \%$ of total resources, followed by cohesion policy with 35\%. Expenditure programmes directly related to the Lisbon objectives account for less than one tenth of overall spending. 
Figure 2: EU budget composition 2007-2013

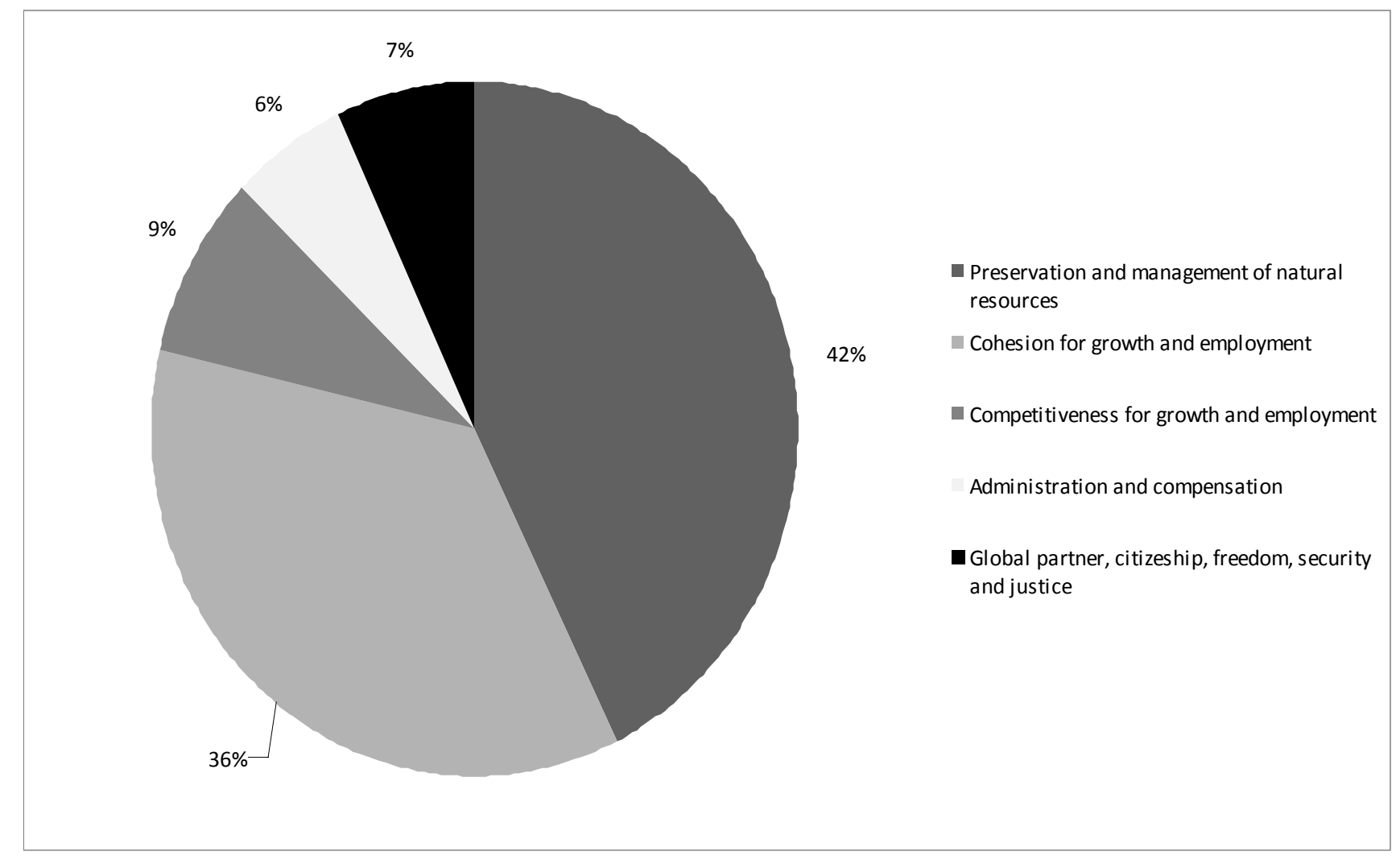

Source: Authors' calculations based on DG Budget

The EU budget is mostly financed from contributions by member sates that broadly reflect the size of their economies. Currently, the budget of the Union is financed through three main resources: 1) traditional own resources (customs and agricultural levies) and other minor revenues make up a small and shrinking part of the budget at around $16 \%$; 2) a VAT resource, also representing $16 \%$; and 3) a resource based on the GNI that plays a residual role to ensure a balanced budget and provides around $67 \%$ of total resources.

Most key issues related to the reform of the EU budget have been widely discussed. First, there is the general conflict between member states who are net contributors and net beneficiaries in terms of the budget size (Cipriani 2007, Le Cacheux 2005). Furthermore, the inability to agree on appropriate composition of the budget has led to a number of adjustments 
-such as the UK rebate and similar arrangements for other net contributors - that also take centre stage in the budgetary debates (Nunez-Ferrer 2007). The revenue structure of the EU budget has also come under discussion, with some member states and European institutions supporting an increase in the role of GNI and/or a new European own resource (DG Budget 2009).

The overall discussion of the EU budget, however, largely boils down to two main issues. First, the definition of what are the types of spending that are desirable at the EU level and, second, net balances. There is overall agreement that the EU should only spend resources in areas where there is added value from doing so at the Community level (Tabellini 2003). However, there is no consensus on what actually constitutes added value. Economic rationalisation of EU-level intervention traditionally points at market failure - notably economies of scale/scope, externalities and public goods - since they are associated with the under-provision of goods and services in the absence of government intervention. In the case of economies of scale and scope, EU intervention promotes efficiency, as larger scale production leads to decreases in the long-run average unit costs (scale) and as the increase in the number of policies administered at the EU level creates synergies in production and distribution (scope). Similarly, in markets where there are significant externalities, ie benefits or costs that accrue not only to the individuals in a country directly involved in the transaction but also to others in the EU, centralisation can allow for the appropriate distribution of compensation and costs. For instance, significant economies of scale/scope and externalities are thought to be present in R\&D and defence policies (Tabellini 2003). As for the case of public goods - usually defined as those with non-rivalrous and non-excludable consumption - 
we take a broader view to encapsulate all expenditures in which the EU adds value, ie improves the overall welfare of EU citizens. ${ }^{1}$

The second key issue relates to how to break down the excessive focus of member states on net balances, ie how much they contribute to the EU budget minus the direct monetary benefits they obtain from EU budgetary allocations (among others Begg 2005, Cipriani 2007, de la Fuente et al. 2008, Le Cacheux 2007, Sapir et al. 2003; Tabellini 2003). Net balances are an issue in themselves for member states that are net contributors to the EU budget since, clearly, all else being equal, everyone would prefer to pay less than more. But net balances also differ across countries with similar output levels, as is the case with the UK and France for example (Figure 3).

Figure 3: Operating net balances (as a \% of GNI, 2007)

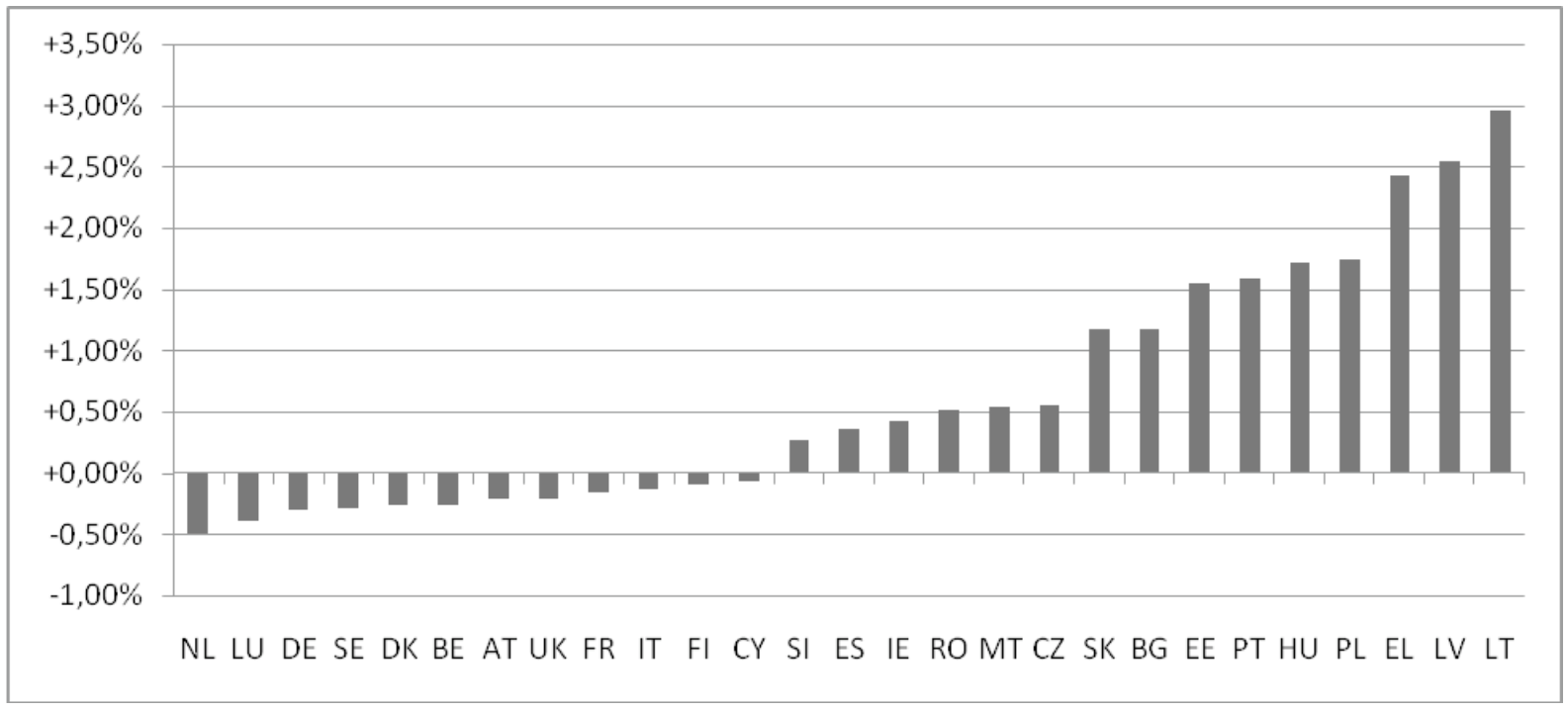

Source: European Commission (2008), EU Budget 2007. Financial Report

\footnotetext{
${ }^{1}$ This paper does not seek to define EU public goods and those areas on which the EU should spend resources. Rather, we focus on the decision-making process and leave the definition of EU public goods to the political process, as will be discussed below. For a thorough discussion of what constitutes EU value added, see Begg (2005), Persson et al. (1997) and ECORYS Nederland BV et al. (2008).
} 
These cross-country differences in net balances across countries of similar wealth indicates that member states are being "compensated" elsewhere and higher net balances therefore represent a payment for those other non-pecuniary benefits. These benefits could be integration gains related to market access as is often argued in the case of Germany (Feld 2006). But, in the absence of an acceptable mechanism, member states seek to 'adjust' the composition of spending and use alternative compensation instruments such as the existing rebates for the UK, Austria, Germany, Sweden and the Netherlands (Begg and Heinemann 2006). Net balances are, therefore, a political outcome. As a result, the pervasive relationship between net balances and spending decisions will not be severed until there are changes to the decision-making process. The present decision-making procedures lead to net-balancing and, more importantly, to distorted spending decisions. This is precisely the rationale of our paper. As discussed in the introduction, we propose a new decision-making process for the EU budget that allows for horizontal compensation across countries and paves the way for increased focus of EU expenditures on those policies that provide added value at the EU level.

Next, we briefly take a look back in time to understand interactions between net balances (and side-payments) and spending.

\section{Net balances and EU spending}

Historically, side-payments have been part of budgetary negotiations and an important part of spending decisions. The first 30 years of EU finances, between 1958 and 1987, were marked by several conflicts both between member states in the Council and between the Council, the Parliament and the Commission. 
In the 1970s, as customs duties and agricultural levies were allocated directly to the Community budget and the VAT own resource was introduced, disputes between member states took centre stage. In the run-up to the 1970 own-resource decision, a bargain was struck between France, which wanted an "automatic" system for the financing of agricultural expenditure, and the other member states, which wanted France to give up its opposition to accession talks with the UK, which resulted in acceptance of the new resources by all member states (Pollack 2008). The fait accompli mounted by the UK - which argued that its share of financing was disproportionate to the return they received from the budget due to their economic structure and trade pattern - caused a major conflict. After ten years of disputes in which the concept of net positions was discussed explicitly for the first time, the UK rebate was introduced in 1984 (Lindner 2006).

By the end of the 1980s, the southern enlargement had increased heterogeneity between member states, resulting in a blockade within the Council. After their accession, Spain and Portugal could form a blocking minority together with Italy, Greece and Ireland, averting the cutting of structural spending. Conversely, the other member states could block any increase in structural spending. A similar deadlock occurred in the case of agricultural spending. For 1988, the Council was unable to decide on a draft budget in the annual procedure (European Commission 2008, Lindner 2006).

The final years of the 1980s also saw important changes in terms of the EU budget decisionmaking process, in particular in relation to the introduction of the multi-annual financial planning for the period 1988 to 1992 (European Commission 2008). Controversial financial issues were left to heads of state or government who unanimously determined allocation of funds to policy areas by fixing spending ceilings. Among other innovations, a doubling of 
structural spending envisaged in the package provided compensation for southern member states who partly opposed the planned market integration (Pollack 1995).

The 'financial perspectives' considerably reduced the room for manoeuvre in the annual budgetary procedure. Changes in the multi-annual framework, moreover, were subject to strict rules. This ended the conflicts over the annual budget that dominated the pre-1988 period, yet in some respects debates were simply shifted to the level of the European Council.

The 'financial perspectives' have been renewed three times: Delors II (1993-1999), Agenda 2000 (2000 to 2006) and the Financial Programme from 2007 to 2013. The Delors I blueprint, in particular the linkage to policy priorities and the bundling of policy reform and budget decisions, has been retained. The preparation for the euro was reflected in Delors II mainly in terms of expenditures on poorer areas, namely Spain, Portugal, Greece and Ireland, which needed resources to help them catch up with the other economies. A new cohesion fund was established, providing funds for countries rather than regions as in the structural funds. Eligibility for the cohesion fund was set at a GDP per capita of less than $90 \%$ of the Community average at country level, thus ensuring that only Spain, Portugal, Greece and Ireland would qualify for support. An even more openly tailor-made reform of the Structural Funds was linked to the enlargement in the mid of the 1990s. The introduction of a new Objective 6 for thinly populated regions provided the new Nordic member states with structural funds (Baldwin et al. 1997).

Although intended as a fundamental reform package preparing the EU for enlargement to the east, the Agenda 2000 framework did not stray from the beaten path. Proposals for more fundamental reforms failed (Iozzo et al. 2008). Instead, further exemptions with rebates for Germany, the Netherlands, Austria and Sweden were added. The financial burden of the first 
years after enlargement in 2004 was handled within a constant own-resources ceiling. In the run-up to enlargement negotiations, CAP spending was fixed in real terms until 2013. New member states are being phased in gradually to the EU's policies.

There is widespread agreement among independent observers that the current financial programme still provides little funding for areas where EU spending is deemed to have added value (ECORYS Nederland BV et al. 2008). The issue of side-payments remains acute. The current financial framework includes many provisions that allocate resources to member states beyond general allocation rules (Council of the European Union 2005). This is particularly true for structural policy. The Council had laid down ex ante in great detail the eligibility criteria for the structural funds and the distribution of resources to the different instruments and objectives. But the final agreement includes a long list of additional provisions that provide extra money for old and new, rich and poor, small and big member states alike. Table 1 (overleaf) summarises the additional provisions of the European Council agreement of December 2005 vis-à-vis those that were already in the Luxembourg presidency's final proposal. 
Table 1: Financial framework 2007-2013, subheading Cohesion, provisions added at the final agreement stage, December 2005

\begin{tabular}{|l|c|c|}
\hline Member state & $\begin{array}{c}\text { Additional provision } \\
\text { (€million) }\end{array}$ & Share of total Cohesion \\
& 150 & provision per member state \\
\hline Austria & 200 & $11,53 \%$ \\
Czech Rep & 50 & $0,84 \%$ \\
Estonia & 100 & $1,53 \%$ \\
France & 300 & $0,79 \%$ \\
Germany & 140 & $1,28 \%$ \\
Hungary & 1400 & $0,62 \%$ \\
Italy & 80 & $5,46 \%$ \\
Latvia & 2150 & $1,94 \%$ \\
Spain & 150 & $6,82 \%$ \\
Sweden & $8,92 \%$ \\
\hline
\end{tabular}

Sources: Council of the European Union (2005): Financial Perspective 2007-2013, Brussels, 19 December 2005 ,

15915/05, CADREFIN 268, European Commission (2006): inforegio factsheet, Eurostat

Adding up the provisions included only in the final agreement, they account for $1.5 \%$ of total cohesion spending between 2007 and 2013 but have a widely differing impact for individual member states. While Hungary receives $0.6 \%$ of total cohesion spending through the extra money, it represents as much as $6.8 \%$ of total cohesion spending in Spain, $8.9 \%$ of total cohesion spending in Sweden and 11.5\% of total cohesion spending in Austria for the period under consideration.

While in the Luxemburg presidency proposal additional provisions where at least partly based on a rule that can be characterised as general, everything added at the final agreement stage is purely selective and discretionary in nature. It is a clear example of side-payments needed to ensure unanimous agreement.

In sum, the past 50 years show that, despite major reform efforts, the EU budget's structure is highly resilient and the status quo predominates. Overall, the share of agricultural spending declined while structural spending increased. The two items together, however, form an 
utterly stable block of $80 \%$ (Figure 4). Within the rest, reclassifications of spending in line with changing political priorities and recommendations to concentrate more on "public goods" have not reduced the share spent on the CAP and structural policies. This is especially striking for the new "Competitiveness" category, meant to underpin the accomplishment of the Lisbon objectives. ${ }^{2}$

\section{Figure 4: Breakdown of expenditure, multi-annual financial frameworks, initial}

\section{agreements}

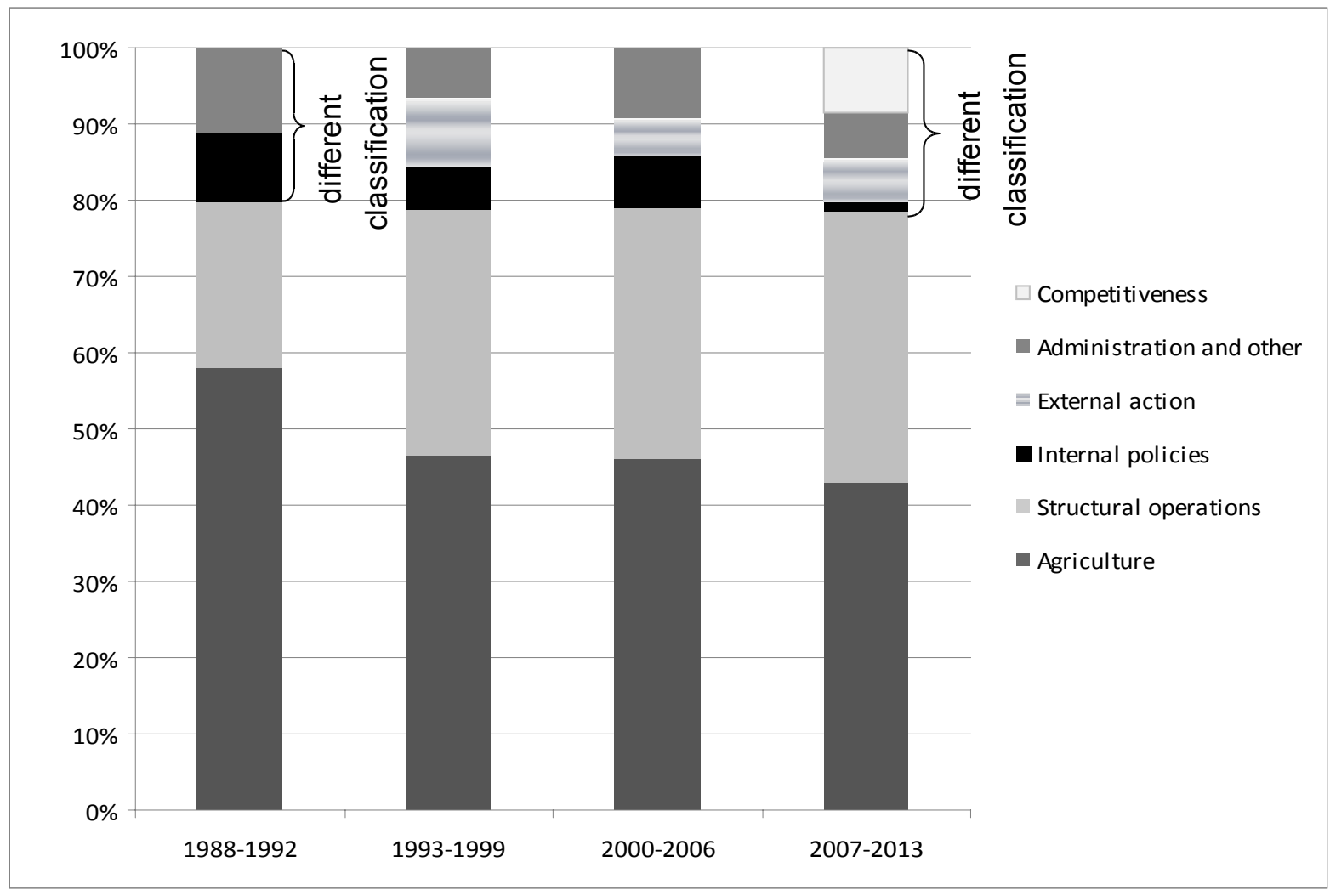

Sources: European Commission (2002): European Union Public Finance, Luxembourg, pp. 38, 57 and 82; European Parliament, Commission, Council (2006): Interinstitutional Agreement between the European

\footnotetext{
${ }^{2}$ The Commission's proposal for the Financial Framework envisaged increasing the share spent on competitiveness from $7.5 \%$ of the budget in 2006 to $13 \%$ on average between 2007 and 2013 . The final agreement, however, raised this share to an annual average of only $8.6 \%$. Other public good spending categories, "EU as a global partner" and "Citizenship, Security, Freedom and Justice", followed a similar path through the negotiation process (European Commission 2005 and European Parliament, Commission, Council 2006).
} 
Parliament, the Council and the Commission on budgetary discipline and sound financial management, Official Journal of the European Union, C 139, 14.6.2006.

Going forward, disagreements among member states are likely to remain. There are diverging views related mainly to the CAP and cohesion policy. Member states' views on the CAP can be grouped in two blocks; on the one hand, France, Hungary, Ireland, Latvia, Poland, Portugal, Romania and Spain would like to see the status quo preserved, while the rest supports some type of more rapid transfer of resources from direct aid and market support in agriculture to rural development. The discussion on cohesion policy, similarly, reflects different views. While a majority of member states would like to have a cohesion policy focused exclusively on poor regions - whether in poor or rich countries - the remainder are in favour of the current situation where all regions receive some measure of support. Similar disagreements also exist on the revenue side, with a vast majority of member states in favour of eliminating the VAT resource but no consensus on whether the GNI resource should be the sole source of funding. Even less agreement exists on whether to introduce an EU tax.

Without a reform of the decision-making process it is difficult to foresee how the vicious circle of net balances and distorted spending can be broken. Several proposals have been made to address this issue. We turn to this next.

\section{Reform in the EU budget decision-making process. A critical look at the literature}

A number of proposals to reform the EU budget have stressed that changes in the decisionmaking process are a necessary condition for more efficient EU finances. As early as 2003, the Sapir report highlighted the different nature of expenditures on EU public goods and those on redistribution (Sapir et al. 2003). In particular, the authors divide EU expenditures into 
three different funds, one for EU growth policies, one for convergence and the third one for economic restructuring.

In fact, the categorisation of EU expenditures dates back to the very beginning of the European integration process. As far back as the Treaty of Rome, the financing of the EU budget differed by category of spending (Table 2). While in the minutes of foreign ministers' negotiations on the Treaty of Rome ${ }^{3}$ it is not clear exactly how the burden-sharing was decided, it is evident that administrative and European Social Fund (ESF) expenditures, the two components of the budget at that time, were viewed distinctly. For administration expenditures, member states accepted as a principle to share the burden proportionally to their capacity to pay (GNI). For the European Social Fund, the relative contributions of member states were adjusted for redistributive purposes. In particular, a lower Italian and Dutch contribution share to the European Social Fund was counterbalanced by larger shares mainly of the other big member states.

Table 2: Financing shares as laid down in the Treaty of Rome

\begin{tabular}{|l|l|l|}
\hline Member state & Administration & European Social \\
& & Fund \\
\hline Belgium & 7,9 & 8,8 \\
\hline Germany (West) & 28,0 & 32,0 \\
\hline France & 28,0 & 32,0 \\
\hline Italy & 28,0 & 20,0 \\
\hline Luxembourg & 0,2 & 0,2 \\
\hline Netherlands & 7,9 & 7,0 \\
\hline
\end{tabular}

Source: Article 200 of the treaty setting up the European Economic Community

The financing mechanism for the EU budget decided in the Treaty of Rome parallels a separation between expenditures related to "public goods" and the rest, with administration -

\footnotetext{
${ }^{3}$ Konferenz der Aussenminister, Sekretariat, Brüssel, 12. Februar 1957: Entwurf eines Protokolls der Konferenz der Aussenminister der Mitgliedstaaten der EGKS, Brüssel, 26., 27., 28. Januar und 4. Februar 1957, provided by the Historichal Archives of the European Union, Florence, fond-number CM31 NEGO 96.
} 
clearly a EU public good - being financed by national contributions proportional to GNI and the other policies largely reflecting a solidarity rationale.

However, a policy that at one point in time is considered a public good may not continue being so in the future. This has been the case, for instance, of the CAP. While initially financed as a public good, ie roughly proportionally to GNI, it has over time been financed in a more ad-hoc manner, even during the time of national contributions (Table 3). In other words, different circumstances may call for different definitions of public goods. This also highlights the fact that while the border between public goods and distributive expenditures is fairly clear conceptually, in practice it is much less so.

Table 3: Financing shares of the CAP 1962 to 1970

\begin{tabular}{|l|l|l|l|l|l|}
\hline Member state & $1962-1965^{1}$ & $1965 / 66$ & $1966 / 67$ & $1967-1969^{2}$ & 1970 \\
\hline Belgium & 7,9 & 7,95 & 7,95 & 8,10 & 8,25 \\
\hline Germany & 28,0 & 31,67 & 30,83 & 31,20 & 31,70 \\
(West) & & & & & \\
\hline France & 28,0 & 32,58 & 29,26 & 32,00 & 28,00 \\
\hline Italy & 28,0 & 18,00 & 22,00 & 20,30 & 21,50 \\
\hline Luxembourg & 0,2 & 0,22 & 0,22 & 0,20 & 0,20 \\
\hline Netherlands & 7,9 & 9,58 & 9,74 & 8,20 & 10,35 \\
\hline
\end{tabular}

${ }^{1} \mathrm{~A}$ minor adjustment was made based on net imports from third countries.

${ }^{2}$ This does not include tariff revenue.

Source: Peffekoven, R. (1994): Die Finanzen der Europäischen Union, Mannheim, p. 48

The categorisation of expenditures in the EU budget has also been taken as the starting point for more recent proposals. Three of these are of special relevance for this paper - de la Fuente et al. (2008), Heinemann et al. (2008) and Iozzo et al. (2008) ${ }^{4}$ - and have served as a rationale

\footnotetext{
${ }^{4}$ Here, we focus on those three schemes that are the closest to our own approach. We do not discuss a series of other proposals that also start from the principle of separation of expenditures, but have quite a different approach. For instance, Blankart and Kirchner (2004) design a system to decide on the expenditures on EU public goods whereby each member state puts forward their own proposed budget. To the 27 proposals, the status quo is also added. Each member state then, sequentially, vetoes one proposal. The surviving budget is adopted.
} 
for this research. We briefly discuss their contributions and try to identify limitations. We aim to address these limitations in our proposal.

The main issue all three papers try to resolve is that of fairness of net balances and the resulting distribution of EU expenditures. All three groups of authors put forward a version of a correction mechanism, inspired by the proposals of the Commission (European Commission $\left.2004^{5}\right)$. The closest to the spirit of the general correction mechanism is Heinemann et al. (2008). The authors propose a generalised but limited correction mechanism. It differs from the Commission's proposal in that it excludes expenditures that "can not be allocated to individual countries due to the nature of payments" and those that "may be identifiable but this payment is no sensible proxy for the share of country benefits from that policy" (Heinemann et al. 2008). In other words, the authors leave EU public goods out of the calculation of the relevant net balances for the correction payments. While addressing the fairness of net balances, both the limited and the non-limited version of the generalised correction mechanism risk changing little of the incentives to spend more on EU public goods. This proposal would lead to more EU public goods if net balances were determined by financial considerations only. However, the mere fact that net balances vary across countries with the same level of GNI per capita goes to show that they serve as compensation for other non-pecuniary benefits and/or interests. For example, even under Heinemann et al.'s scheme, member states with influential agricultural lobbies might prefer a large Common Agricultural Policy, even if this is not in the interest of the EU as a whole. That is, as they take a limited financial view of net balances, these correction mechanisms on the revenue side might lead to alternative compensations and adjustment arrangements to the detriment of the same public goods' expenditures that the system is meant to promote.

\footnotetext{
${ }^{5}$ This mechanism looks to cap the maximum net contributions of member states to the EU budget, expressed as a percentage of national GNIs. It does this through a partial reimbursement of their net contributions; if the threshold decided upon is exceeded, a percentage of every additional euro spent is refunded to the country. All member states, except the beneficiary country, contribute to these rebates. In essence, this proposal represents an extension of the existing UK correction.
} 
De la Fuente et al. (2008) highlights one additional limitation of the general correction mechanisms, namely that only net payers benefit from adjustments. The authors try to overcome this limitation by designing a broader mechanism that aligns net balances with relative prosperity. They propose a system of horizontal transfers across member states as determined by differences in real income per capita. They leave open, however, the possibility of adjusting transfers to achieve a larger degree of cross-country distribution, since their original scheme leads to redistribution towards richer member states compared to the status quo. In addition, their scheme envisages a different source of finance for EU public goods, with either equal per capita sharing all across the EU or in proportion to member states' output. Yet once overall net balances are fixed, the financing becomes largely irrelevant. Here, as with Heinemann et al. (2008), this proposal focuses on the fairness of burden-sharing but also leaves largely unchanged the incentives to increase the share of EU public goods in the EU budget, given its focus on financial net balances. Again, member states have an incentive to look for adjustments elsewhere, ie on the expenditures side, distorting further the expenditure decision on EU public goods.

Iozzo et al. (2008) adopt the proposal by de la Fuente and co-authors but propose different financing. In particular, they strive for the economically efficient solution to finance EU public goods with an EU tax, leaving the rest of the budget to be financed by GNI contributions. While an EU tax is theoretically attractive and is a desirable goal for the EU, there is little appetite for it currently. ${ }^{6}$

\footnotetext{
${ }^{6}$ Regarding revenues, a vast majority of member states is in favour of eliminating the VAT resource but major disagreements remain on whether the GNI resource should be the sole source of funding. Only Belgium, Luxembourg and Poland explicitly support the introduction of a new EU own resource, like an EU tax, although several more member states are open to the idea in principle. Bulgaria, the Czech Republic, Denmark, Germany, Ireland, Lithuania, Malta, the Netherlands, Slovakia and Sweden overtly oppose it. Finally, most member states
} 
While capping net balances and addressing the fairness issue of financial contributions, these three proposals fall short on two important accounts. On the one hand, they minimise the importance of non-financial factors in determining net balances, de facto strengthening the role of net balances. Additionally, these proposals do not create the necessary incentives to change the composition of expenditures, which is the ultimate aim of any budgetary reform. In this context, our proposal tries to affect the budgetary outcomes more directly by providing a feasible solution that both accommodates political and financial constraints and moves the EU budget closer to efficiency and improves EU value added. We discuss the details of our reform proposal below.

\section{Our proposal}

The EU budget should be a reflection of the Union's common policies and goals. Policy reform, however, will not arise exogenously. It requires a change in the institutional setting and procedures. In other words, we need to alter existing incentives in order to promote a change in policies. With this in mind, in this section we propose a new decision-making process for the EU budget that takes into account existing political and financial constraints.

From our discussion in previous sections, two main lessons arise that should be incorporated into any proposal that hopes to be practical and implementable. First, there is a strong status quo bias or path dependency in deciding the EU budget. Second, net balances play a key role for member states' decisions regarding EU finances. Both of these aspects need to be taken as initial constraints for budget reform proposals. The biggest challenge is, therefore, to design a process that generates, from within, incentives for change.

\footnotetext{
- not surprisingly - oppose corrections of contributions.
} 
We propose separating the budget into a redistributive and a public good part and combine it with two suggestions regarding the negotiation process and the financing of the EU budget. On the one hand, in order to reveal common interests, the decision on what is to be considered as an EU public good is left to the negotiation process. On the other hand, while public goods should be financed proportionally to GNI shares, we argue that the adjusting of net balances for the financing of redistributive policies should be allowed. In what follows, we present the details of this proposal, calculate possible net balances as an illustration of its implementation and, finally, discuss its merits vis-à-vis other reform proposals for the EU budget decisionmaking process put forward in the recent past.

While previous schemes to separate the budget into redistribution and public good parts do not specify how to define the different categories, take fiscal federalism to derive criteria for the categorisation or do not differentiate the source of financing of the different expenditures, we suggest that it is up to member states themselves - through unanimous decision - to decide. We propose to endogenise the decision on what constitutes a public good; a unanimous decision in fact reveals a common belief that a specific policy should be an EU task. These will clearly be policies from which all member states derive benefits.

We propose a two-stage process:

- First stage: Starting from the current financial framework, member states decide unanimously which expenditure categories (or parts of expenditure categories) are to be considered to be in category 1 or public good expenditures. All remaining expenditures by default go into category 2 .

- Second stage: Member states fix expenditure ceilings for each category independently. 
- Category 1 of public goods - once EU traditional own resources are accounted for - are to be financed proportionally to GNI as an indicator of wealth. Since policies in this category have been unanimously considered an EU public good, there can be no exemption.

- Category 2 - fix the overall net balance by member state. For the first negotiation, heading ceilings and member states' net balances can be established at the same level as in the status quo according to the calculations made by the European Commission (European Commission 2008). By starting from the status quo, both in terms of policies and net balances, we recognise that zero-based budgeting, although ideal, is not realistic. This effectively separates the discussion on policies from the discussion on procedures. ${ }^{7}$

Any new policy that is to be added to the EU expenditure programme should by definition be unanimously agreed on, and go to category 1 . The need for consensus in defining what is a public good and what is not reveals common interests. Our proposal stresses that category 1 expenditures - or EU public goods - are to be financed in proportion to GNI while making explicit net balances for all other expenditures.

In sum, our proposal, while not automatically leading to drastic compositional changes in expenditure, would clarify the debate by making the trade-offs between allocation and (re)distribution explicit. By increasing transparency about the nature of EU expenditures it would create incentives to move towards category 1 or EU public goods expenditures. It then

\footnotetext{
${ }^{7}$ There are several possibilities for financing non public-goods expenditures, ranging from the current mixed system of traditional own resources, VAT and GNI to only GNI, national contributions or an EU tax. This is an important issue that we do not tackle in this paper.
} 
becomes harder to justify other expenditures that are mainly redistributive and not accepted by all member states.

As an illustration, we have considered the possible effects of this reform on member states' overall net balance. Starting from the current financial framework, we consider expenditures of the following headings as public goods: "Competitiveness for growth and employment", "Cohesion Fund", "Citizenship, Freedom, Security and Justice”, "EU as a global player" and "Administration". This leaves the structural funds and expenditures for the "Preservation and Management of Natural Resources" (mainly CAP) as category 2 expenditures. This is only an indicative division of expenditure since, as discussed above, the ultimate division should arise from the unanimous decision of member states. However, it does seem to be a feasible outcome given the official positions expressed by member states. In this case, probably only few expenditures (such as administration, foreign policy) would make it into category 1; other expenditures may only partly make it into category 1 , as is the case of structural policies where the Territorial Cooperation Objective could be considered an EU public good.

This exercise leads to very minimal changes in net balances. The resulting changes are less than $10 \%$ of original net balances for 25 member states and less than $5 \%$ for 22 (Figure 5). If, instead, one calculates net balances on the basis that all expenditures are financed proportionally to GNI, the changes are also small, with the exception of the UK, whose net balance would worsen by 5 billion euros (Figure 6). This points to the possibility of an intermediate solution, phasing out the UK rebate by excluding public goods unanimously agreed upon from its calculation. The UK argumentation for introducing the rebate was based on their opposition to redistributive policies. This new procedure should then facilitate their willingness to gradually give up the rebate. 
Figure 5: EU budget net balances under our proposal, 2007, €billion

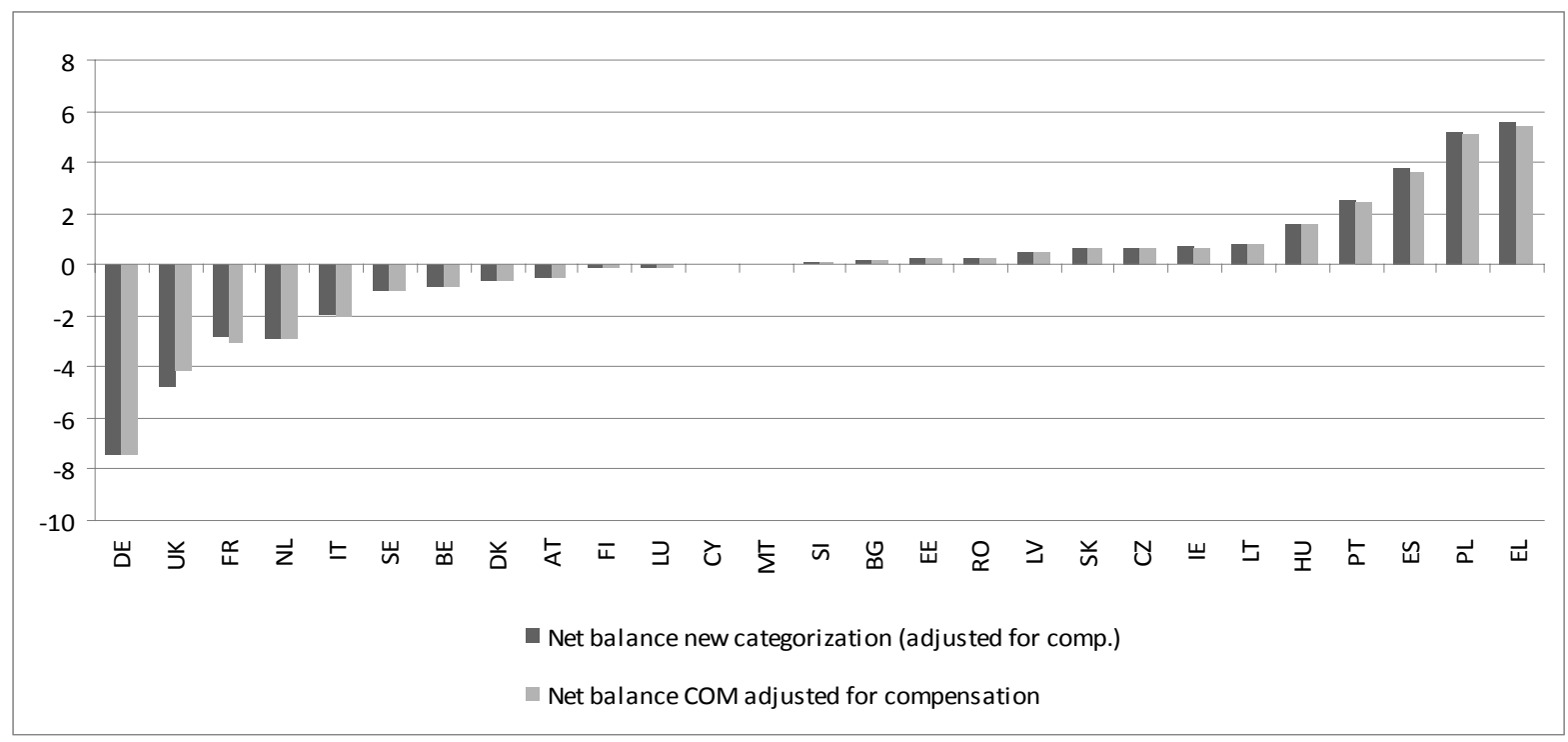

Source: European Commission (2008), EU Budget 2007. Financial Report, authors' calculation

Figure 6: EU budget net balances with only GNI-based financing, 2007, €billion



Source: European Commission (2008), EU Budget 2007. Financial Report, authors' calculation

Our proposal makes explicit the different character of EU policies. On the one hand, some EU policies clearly have the characteristics of public goods; on the other, there are spending programmes whose underlying purpose is clearly redistributive or compensatory. 
Our proposal seeks to pave the way for future reform of the EU budget that allows for an increasing share of expenses that benefit the EU as a whole. For this, we have purposely remained within the constraints imposed by the current political and economic environment. As such, our proposal is by no means a first-best solution to existing budgetary issues. The proposal rests on two pillars: (1) the separation of public goods and redistributive expenditures as decided by the Council's unanimous vote; and (2), a different financing structure for each category, with public goods being financed according to GNI shares and the rest of the expenses just as today.

As mentioned at the beginning of this section, the literature has already discussed several proposals to address the shortcomings of the decision-making process of the EU which also start from a separation of EU public goods. Therefore, this aspect is not new but, in contrast to de la Fuente et al. (2008) and Iozzo et al. (2008), we - as do Heinemann et al. (2008) - leave the definition as to what is to be considered public goods to the budgetary negotiations.

In terms of the second pillar of our proposal, there are two fundamental differences with all three previous work. First, in contrast with our focus on negotiated net balances, all three alternative proposals favour some version of a general correction mechanism based on quantitative criteria and in the spirit of the proposal by the Commission (European Commission 2004). We have argued, however, that a correction mechanism, while addressing relative burden-sharing concerns, does little in terms of the distribution, and therefore the quality, of expenditures. Since the latter should be the ultimate goal of any EU budget reform, our proposal does not include any capping of net balances.

Second, the financing structure of EU expenditures varies across the board. De la Fuente et al. (2008) focus on the need to finance public goods proportionally according to member states' 
population or GNI, but they do not discuss in further detail how other expenditures are to be financed. Iozzo et al. (2008), on the other hand, favour an ambitious approach to financing. They propose a EU tax to finance EU public goods and GNI as a revenue source for the rest of the budget. While, from an efficiency perspective, it is desirable to have an EU tax for EU public goods, this is more a long-term option than an immediate possibility. Finally, and closer to our proposal, Heinemann et al. (2008) recommend relying solely on GNI for all financing within the framework of their proposed generalised limited correction mechanism.

In short, the proposal put forward in this paper seeks a solution that is both practical and efficient in accommodating different national interests while striving for an increased focus on resources for EU public goods. Two main lessons from this time relate to our proposal and are relevant for today's debate. First, there is a precedent for countries contributing in different capacities to different policies. Second, what is considered a public good may change over time. Acknowledging the importance of net balances for member states during the negotiating process is fundamental for any politically do-able reform proposal. Nevertheless, the ultimate goal of EU budget reform proposal should remain that of facilitating the transfer of funds towards those policies that are considered to provide EU-wide benefits. 


\section{References}

Baldwin, Richard E; Francois, Joseph F and Portes, Richard D. (1997), The costs and benefits of eastern enlargement. The impact on the EU and Central Europe. In: Economic policy, pp. $125-176$.

Begg, Iain and Heinemann, Friedrich (2006), New Budget, Old Dilemmas. (Centre for European Reform Briefing Note, 22nd February 2006).

Begg, Iain (2005), Funding the European Union: Making Sense of the EU Budget: A Federal Trust Report on the European Union's Budget.

Blankart, Charles B. and Kirchner, Christian (2004), The deadlock of the EU budget: An economic analysis of ways in and ways out." In A constitution for the European Union, edited by Charles B. Blankart and Dennis C. Mueller. Cambridge, Mass.: MIT Press.

Cipriani, Gabriele (2007), Rethinking the EU Budget: Three Unavoidable Reforms. Brussels. Council of the European Union (2005), Financial Perspective 2007-2013, Brussels, 19 December 2005, 15915/05.

de la Fuente, Angel, Doménech, Rafael, and Rant, Vasja (2008), Addressing the net balances problem as a prerequisite for EU budget reform: A proposal.

http://ec.europa.eu/dgs/policy_advisers/conference_docs/de_la_fuente_net_balance_budget .pdf, accessed June 2008 .

ECORYS Nederland BV, Netherlands Bureau for Economic Policy Analysis (CPB), Institute for Economic Research (IFO) (2008), A Study on EU Spending. Final Report. Available online at http://ec.europa.eu/budget/reform/library/issue paper/study_EUspending_en.pdf, accessed May 2009. 
European Commission, DG Budget (2009), Contributions to public consultations on the EU budget, available at http://ec.europa.eu/budget/reform/issues/read_en.htm, accessed May 2009.

European Commission: European Union public finance. 4. ed. (2008), Luxembourg: Office for Official Publications of the European Communities.

European Commission (2008), EU Budget 2007. Financial Report.

European Commission (2005), Technical adjustments to the Commission proposal for the multiannual financial framework 2007-2013, Brussels, 12.4.2005, SEC(2005) 494 final.

European Commission (2004), Financing the European Union. Commission report on the operation of the own resources system. Technical Annex. Volume 2. Brussels. (COM(2004) 505 final).

European Parliament, Commission, Council (2006), Interinstitutional Agreement between the European Parliament, the Council and the Commission on budgetary discipline and sound financial management, Official Journal of the European Union, C 139, 14.6.2006.

Feld, Lars P. (2006), Nettozahler Deutschland? Eine ehrliche Kosten-Nutzen Rechnung. In: Wessels, Wolfgang; Diedrichs, Udo (ed.): Die neue Europäische Union: Im vitalen Interesse Deutschlands? Studie zu Kosten und Nutzen der Europäischen Union für die Bundesrepublik Deutschland. Berlin , pp. 93-113.

Gros, Daniel, and Micossi, Stefano (2005), A Better Budget for the European Union: More Value for Money, More Money for Value. CEPS Policy Brief No. 66.

Heinemann, Friedrich, Mohl, Philipp, and Osterloh, Stefan (2008), Reform Options for the EU Own Resources System, Heidelberg: Physika-Verlag.

Iozzo, Alfonso, Micossi, Stefano, and Salvemini, Maria Teresa (2008), A new budget for the European Union? CEPS Policy Brief No. 159. 
Le Cacheux, Jacques (2005), European Budget: the poisonous budget rebate debate. (Notre Europe Studies, 41).

Le Cacheux, Jacques (2007), Funding the EU Budget with a Genuine Own Resource: The Case for a European Tax. Notre Europe Studies No. 57, http://www.notreeurope.eu/uploads/tx_publication/Etud57-FundingtheEUBudget_03.pdf, accessed July 2008 .

Lindner, Johannes (2006), Conflict and change in EU budgetary politics. London: Routledge (Routledge advances in European politics, 32).

Núñez Ferrer, Jorge (2007), The EU budget: The UK rebate and the CAP - Phasing them both out? Brussels: Centre for European Policy Studies.

Persson, Torsten; Roland, Gérard and Tabellini, Guido (1997), The Theory of Fiscal Federalism: What Does It Mean for Europe? In: Siebert, Horst (ed.): Quo vadis Europe? Tübingen: Mohr, pp. 23-41.

Pollack, Mark A. (2008), Member-State Principals, Supranational Agents, and the EU Budgetary Process, 1970-2008. http://ec.europa.eu/dgs/policy_advisers/conference_docs/pollack_eu_budget.pdf, accessed June 2008.

Pollack, Mark A. (1995), Regional Actors in an Intergovernmental Play: The making and Implementation of EC Strucutral Policy. In: Rhodes, Carolyn; Mazey, Sonia (ed.): Building a European polity? Boulder, Colo.: Rienner [u.a.] (The state of the European Union, 3), pp. 361-390.

Sapir, André; Aghion, Philippe; Bertola, Giuseppe; Hellwig, Martin; Pisani-Ferry, Jean; Rosati, Dariusz; Viñals, José, and Wallace, Helen (2003), An agenda for a growing Europe. Making the EU Economic System Deliver: Report of an Independent High-Level Study Group established on the initiative of the President of the European Commission. 
Tabellini, Guido (2003), Principles of Policymaking in the European Union: An Economic Perspective. CESifo Economic Studies 49/1: 75-102. 